\title{
Jurij Bondarev jako ruský fenomén a představitel epochy
}

\author{
Ivo Pospíšil
}

(Brno, Česká republika)

Dne 29. dubna 2020 zemřel v Moskvě ve věku dožitých 96 let (narozen 15. 3. 1924) rodák z Orska v Orenburské gubernii, ruský sovětský spisovatel, povídkář, scenárista, romanopisec, esejista a koneckonců i veřejný činitel Jurij Vasilejvič Bondarev; 2. dubna byl pohřben na Trojekurovském hřbitově. ${ }^{1}$ Zemřel jako poslední představitel generace, která svůj spisovatelský osud spojila s „táním“ druhé poloviny 50. let 2o. století, ačkoli namnoze začala psát o něco dřive: Grigorij Baklanov (1923-2009), Bělorus Vasil’ Bykav (rusky Vasilij Bykov, 1924-2003), Vladimir Bogomolov (1924-2003), Vladimir Těndrjakov (1923-1984) jsou jména, která generaci 6o. let provázela životem. Byli to oni, kdo byl ostře protistalinistický, depatetizovali literaturu, přehodnotili tzv. válečnou prózu, vytvořili znovu postavu malého ruského člověka, řadového vojáka. Esteticky nepřekročili práh tradičního realismu, $v$ lecčems tendenčního, rozhodně nenavazovali na ruskou modernu ani avantgardu, spíše na klasické postupy 19. století, původně všichni byli oficiálně oceňovanými představiteli sovětské epochy, i když její lidštější tváře; měli představu obnovené humanity, ale v rámci dané ideologie, což se většinou ukázalo jako iluzorní. Ale jen pro některé byl pád sovětského režimu a rozpad SSSR také osobní tragédií: většinou své názory změnili už za perestrojky, zčásti i před ní $\mathrm{s}$ tím, že k zlomové situaci v sovětské inteligenci, která podporovala režim, byt’ s výhradami, byl konec 6o. let a určitě i pražské jaro a jeho brutální potlačení. Tyto proměny názorů se Bondareva netýkaly. ${ }^{2}$ Ostatně ani ostatní se neprojevovali nijak radikálně: až na výjimečné události a stanoviska, která bychom mohli haškovsky

1 Bondarevovi jsem se věnoval v rozpětí desítek let běžnými recenzemi v literárních časopisech i denním tisku, ale i samostatnými studiemi: [POSPÍŠIL 1975; POSPÍŠIL 1983; POSPÍŠIL 1984; POSPÍŠIL 1985; POSPÍŠIL 1988; POSPÍŠIL 1994; POSPÍŠIL 2002a; POSPÍŠIL 2002b; POSPÍŠIL 2003; POSPÍŠIL 2008; POSPÍŠIL 2011].

2 Např́klad G. Baklanov se zúčastnil známého setkání sovětských spisovatelů a literární emigrace v Dánsku, viz [MAGNUSSON 1989]. Ještě roku 1979 byl však jedním z těch sovětských spisovatelů, kteří odsoudili almanach Metropol. 
označit jako „mírný pokrok v mezích zákona“, nebyli výrazněji potrestáni, jako se to stalo účastníkům almanachu Metropol (12 exemplářủ bylo vytvořeno v prosinci 1978, 1979 na základě vyvezeného exempláře almanach vyšel v USA v Ann Arbor v tehdy proslulém nakladatelství Ardis). Mnozí z kritiků režimu byli současně dlouhá léta jeho hájenou výstavní skř́ní, mohli volně jezdit po světě a režim snášel jejich kritické výpady pronášené v zahraničí i zdánlivě odvážná stanoviska, za něž však - na rozdíl od jiných - nenásledovala odplata (J.Jevtušenko). Bondarev na své protistalinské, ale sovětské pozici zůstal. Vyjadřoval se i proti disidentskému hnutí. Je mnoho záhad, skutečných i zdánlivých, v posledních dvaceti letech SSSR: rozhodně i naše dnešní hodnocení trpí často schematismem, nemluvě o pohledu na prríčiny charakteru tehdejší literatury, např. vesnické prózy. Cesty našich generačních druhů se rozcházely a rozešly postupně od druhé poloviny 8o. let za glasnosti a perestrojky: většina byla nadšena, ale viděla jen jejich lesklý povrch, jiní viděli „za roh“ a tušili problémy, aniž by popírali nutnost změny systému, demokracii a svobodu slova. Bondarev patřil ke kritikům tohoto procesu: známá je jeho alegorie, že perestrojka je jako letadlo, které se ocitlo ve vzduchu a ještě neví, jestli pro ně existuje přistávací plocha.

Dotkl jsem se kdysi několikrát jeho románu Bermudský trojúhelník (Бермудский треугольник, 1999). Tam jsem si v řadě míst uvědomil, jak velkou pravdu měla česká rusistka Světla Mathauserová, když upozornila v souvislosti s jiným ruským dílem, které bývá uzuálně označováno za první ruský román (sám bych dal př̀ednost spíše pojmu „protoromán“) - Životem protopopa Avvakuma (1672-1675) - na hodnotové využívání slovesných časů (perfekta a aoristu): Avvakumův svět se tedy nejen ideově, ale také jazykově štěpí ve dvě hodnotové roviny. Spojitost Jurije Bondareva, ruského (sovětského) spisovatele, kontroverzního včera i dnes, kdysi kritika Stalinova kultu, „mladého buřiče“, který ve svých válečných prózách hledal nikoli „pravdu štábu“, ale „zákopu“, který se nostalgicky ohlížel za sovětskou dobou, ostř̌e kritizoval zejména jelcinovské Rusko (odmítl od Jelcina převzít vyznamenání), který zaujímal a zaujímá společensky kontroverzní stanoviska, ale zůstává věrný svým reformně komunistickým ideálům, a protopopa Avvakuma je užší, než by se mohlo zdát: nejen v obdobné životní pozici (i když se to může zdát podivné) proti proudu, ale i v tom, že se jejich tvưrčí dráhy paradoxně střetly, nebot postava starověrce (raskolnika) Avvakuma Petrova se objevuje př́mo v Bondarevově románu Hra (Игpa, 1985), díle psaném ještě za komunistického režimu v krizi postbrežněvismu, v nejistotě a v očekávání nejasných změn. Nebylo by to poprvé, kdy se Avvakumova postava zjevuje v pozdější ruské literatuře: když pomineme inspiraci Avvakumem, kterou pocítili takřka všichni významní ruští spisovatelé „zlatého věku“ ruské literatury (N. Gogol, F. Dostojevskij, M. Saltykov-Ščedrin) i „stříbrného věku“ (A. Remizov), bylo to u N. S. Leskova v první redakci jeho románové kroniky Soborjane (česky vyšla poprvé a naposledy 1903 péčí rajhradského mnicha Aloise Augustina Vrzala - pseudonym A. G. Stín [POSPÍŠIL 
1993] - jako Duchovenstvo sborového chrámu) Чающие движения воды - podrobněji ji kdysi rozebrala německá slavistka Ingeborg Gollertová [GOLLERT 1969].

Bondarev vešel do českého čtenářského povědomí definitivně na počátku 6o. let 20. století: jeho prvotina Mládí velitelú (Юность командиров, 1956) se do českého prostředí dostala až roku 1963, kdy již byla známější jeho průraznější díla (Prapory žádají palbu, rus. Батальоны просят огня, 1957, česky vyšlo 1960, Poslední salvy, rus. Последние залпы, 1959, vyšly 1961). Po válečných novelách přichází volná dilogie Ticho (Тишина, 1962, с̌. 1963) а Př́buzní (Родственники, 1969, с̌. 1971) s často citovaným „senzačním“ líčením Stalinova pohřbu a tragédie ušlapaných lidí. V těchto chvílích se zdálo, že Bondarev je konjunkturální spisovatel, jehož prózy se k nám překládaly takřka okamžitě, podobně jako básně A. Vozněsenského a J. Jevtušenka (vl. jm. Gangus, 1932/1933-2017 Tulsa, Oklahoma) nebo prózy V. Těndrjakova (1923-1984). Později se čím dál víc ukazovalo, že Bondarev je především prozaikem lidského charakteru, lidské vůle a sebezapření udržet si v toku času, pod tlakem moci a v odzbrojujícím automatismu všedního dne své ideje a přesvědčení, jakkoli kontroverzní a jdoucí proti proudu. Má potřebu být permanentním kritikem, ř́kat jakoby překonané pravdy, provokovat svým konzervatismem: i když se shodoval s chruščovovskou kritikou stalinismu, viděl Rusko mnohem stř́źlivěji než kritičtí, ale současně stále něčím nadšení básníci typu J. Jevtušenka. Bondarev patřil spíše $k$ těm, jejichž tvorba nebyla většinová, byla programově protimódní a protikonjunkturální: bud tím, že byla př́liš radikální (jeho pojetí války, popis Stalinova pohřbu v románu Př́buzní apod.), nebo naopak př́liš konzervativní, když zcela převládla vlna módní negace minulosti. Paradoxní se může zdát jeho spojování pravoslavné staré Rusi se sovětskou dobou, která jí byla vždy nepřátelská: $v$ tom se podstatně lišil od prozaiků a básníků tzv. vesnické literatury i od opozice, jak se projevila např. v almanachu Metropol (1978-1979). Jsou spisovatelé i politici, kteří za života několikrát zásadně mění své názory a postoje, a mají tudíž stále pravdu, stále jdou progresivně kupředu. Vypadá to, že v jejich nitru probíhá autentický souboj, že se vyvíjejí, ale navenek to vypadá spíše jako běžná konverze, která směřuje $\mathrm{k}$ tomu, co je obecně přijatelné. Bondarev je nekonjunkturalista a kontinuita jeho zatvrzelosti je nejpatrnější právě v jeho umělecké tvorbě. Kvalitativně je jeho dílo nevyrovnané, významné je spíše tím, že dokázal vyhmátnout podstatné společenské problémy, i když pro mnohé je traktoval nepřijatelně. To se týká série románů z pozdní sovětské doby (Volba, Bblбop, 1981, Hra, Игра, 1985, Pokušení, Искушение, 1992, Neodporování, Непротивление, 1996, sem patří і Bermudský trojúhelník, Бермудский треугольник, 1999, а Bez milosrdenství, Без милосердия, 2004). Jde v podstatě o impozantní, byt̉ rozporuplnou, kroniku ruské inteligence a jejích skutečných nebo zdánlivých selhání a je pravda, že takové dílo jako znamení doby jinde nevzniklo. Také Bondarevova návaznost nejen ideová (ruská výjimečnost, autochtonnost, nutnost zachovat ruskou tradici, bránit se zhoubnému, 
nemorálnímu Západu, ohlasy slavanofilských myšlenek), ale i stylová a jazyková, na starší vývojové linie v ruské literatuře, je zajímavým rysem jeho poetiky, i když protikladnost těchto představ je zřejmá, nebở sovětský režim byl původně plodem toho nejzápadnějšího myšlení, ideově vznikal v emigrantských kruzích ruských radikálních sociálních demokratů - obou frakcí - jako projev nutné evroipeizace a dokonce amerikanizace Ruska, jak o nich hovořil Lenin $\mathrm{v}$ rámci tzv. světové revoluce, o níž psal i Masaryk, i když každý jinak, nemluvě o pozdější kolektivizaci zemědělství a zničení tradiční ruské vesnice. Spojuje tedy Bondarev historicky nespojitelné, ale to je ostatně v mnohém charakteristické i pro dnešní ruskou politiku.

Jurij Bondarev je představitelem epochy, která se v dnešním Rusku někdy připomíná, ale spíše zapomíná. Kde jsou autoři jako Leonid Leonov, Konstantin Fedin, dokonce i Ilja Ilf a Jevgenij Petrov, Konstantin Simonov, kdysi doslova módní, i Solženicyn je už na okraji zájmu, v popředí jsou jiní, ale jak tomu bude za pár let, nevíme. Nakolik Bondarevovo dílo, dnes v mladé ruské generaci mrtvé, zůstane trvalejší hodnotou nebo bude spíše jen symbolem určité epochy, tu ční jako palčivá otázka.

\section{Bibliografie:}

GOLLERT, I. (1969): N. S. Leskovs Romanchronik „Die Klerisei“. Berlin.

MAGNUSSON, M.-L. (ed.) (1989): The Louisiana Conference on Literature and Perestroika, 2-4 March 1988. Esbjerg.

POSPÍŠIL, I. (1975): O novém románu f. Bondareva (diskuse o románu f. Bondareva Břeh, Voprosy literatury 1975, č. 9). Rovnost 3. 12. 1975, s. 5.

POSPÍŠIL, I. (1983): Proti povrchnosti, váhavosti a zradě (f. Bondarev: Volba, Praha 1983).

Rovnost 28. 9. 1983, s. 4 .

POSPÍŠIL, I. (1984): Próza návratư, účtování a jistot (J. Bondarev: Okamžiky, Praha 1983). Kmen 6/1984.

POSPÍŠIL, I. (1985): Nedat zhořknout bylině lidského žití (f. Bondarev, Igra, 1985). Světová literatura 1985, č. 5, s. 236-238.

POSPÍŠIL, I. (1988): Nezbytnost mravního očištění (furij Bondarev: Hra. Praha 1987). Literární měsíčník 1988, č. 9, s. 127-129.

POSPÍŠIL, I. (1993): Srdce literatury: A. A. Vrzal. Brno 1993

POSPÍŠIL, I. (1994): Neprávem odsouvaný Bondarev. Rudé právo 22. 3. 1994, s. 4.

POSPÍŠIL, I. (2002a): Jurij Bondarev a jeho Bermudský trojúhelník (Recenze s ukázkami). Alternativa Plus, roč. VI, 2002, č. 3-4, s. 38-43. 
POSPÍŠIL, I. (2002b): Žánrová struktura a emblematičnost apokalyptického románu furije Bondareva Bermudský trojúhelník a souvislosti. Slavica Litteraria X 5, 2002, s. 53-62.

POSPÍŠIL, I. (2003): Jazyk literárního díla jako axiologický nástroj: román furije Bondareva Bermudský trojúhelník (K životnímu jubileu prof. Jána Doruly). In: Život slova v dejinách a jazykových vztahoch. Na sedemdesiatiny profesora Jána Dorulu. Bratislava, s. 265-278.

POSPÍŠIL, I. (2008): Diachronní dimenze ruského literárního textu (Puškin - Bondarev Grjakalov). In: LEPILOVÁ, K. a kol.: Text a kontext. Brno, s. 86-107. POSPÍŠIL, I. (2011): Znovu k problému diachronní hloubky literárního textu. In: ORGOŇOVÁ, O. (red.): Jazyk a komunkácia v súvislostiach III. Bratislava, s. 11-19.

\section{Summary}

\section{Yuri Bondarev as a Russian Phenomenon and a Representative of the Epoch}

The author of the present outline demonstrates both the personality and the literary work of Yuri Bondarev (1924-2020), a recently deceased (29 April) Russian writer representing-more or less-the whole Soviet epoch, a controversial conservative who expressed his resistance to post-Soviet, Yeltsin Russia (he even rejected to take over an award from him). Bondarev created three free cycles of novellas and novels: the first one connected with revaluation of the image of the Great Patriotic War against Nazi Germany, the second linked with the analysis of Stalinism and the crisis of Soviet intelligentsia, the third with the criticism of glasnost and perestroika and post-Soviet era paradoxically synthetizing old Russian, Orthodox and Soviet traditions. Only the future will tell us whether his aesthetically unbalanced, now nearly forgotten work survives its epoch.

\section{About the author}

Ivo Pospíšil, Masaryk University, Faculty of Arts, Department of Slavonic Studies, Brno, Czech Republic,ivo.pospisil@phil.muni.cz 
